\title{
Phytoplankton Growth and Regulation in the Labrador Sea: Light and Nutrient Limitation
}

\author{
W. Glen Harrison and William K. W. Li \\ Fisheries and Oceans Canada, Bedford Institute of Oceanography, \\ Dartmouth, Nova Scotia B2Y 4A2
}

\begin{abstract}
Harrison, W. G., and W. K. W. Li. 2007. Phytoplankton Growth and Regulation in the Labrador Sea: Light and Nutrient Limitation. J. Northw. Atl. Fish. Sci., 39: 71-82. doi:10.2960/J.v39.m592
\end{abstract}

\begin{abstract}
The importance of light and nutrients in regulating phytoplankton growth in the Labrador Sea was evaluating using climatological data, 12 years of measurements made as part of the Labrador Sea Monitoring Program (LSMP) and physiological information from the literature. Light limits primary production and phytoplankton growth much of the year, even during summer when surface irradiance is at its seasonal peak. Nutrients, nitrogen (nitrate) and silicate, are reduced to low levels in surface waters in summer/autumn and can limit phytoplankton production and growth at this time of year. Nitrate appears to be the nutrient in shortest supply on the Labrador Shelf while silicate is in shortest supply in the central Labrador Basin. Multiyear trends in regional hydrography (increases in water temperatures, decreases in mixed layer depth) and changes in nitrate and silicate supply over the past decade (i.e. increases in nitrate and decreases in silicate) may be linked to changes in phytoplankton community composition and structure (i.e. decreases in large forms such as diatoms and increases in small picoplankton and nanoplankton forms).
\end{abstract}

Key words: primary production, phytoplankton, Labrador Sea, light, mixed-layer, nitrate, nutrients, silicate.

\section{Introduction}

The distribution, productivity and growth regulation of phytoplankton in high-latitude ecosystems have been the subject of numerous reviews and comprehensive studies (Longhurst, 1981, 2006; Gray and Christiansen, 1985; Francis, 1996; Skjoldal, 2004). Light and nutrients ("bottom-up" regulation) and herbivorous grazing ("top-down" regulation) are the principal factors that set limits on phytoplankton growth in these regions just as in other marine ecosystems. Viral lysis, a significant regulating factor in some systems has been little studied in these waters. Sub-polar and polar light conditions for phytoplankton growth, however, are subject to extreme seasonal variations, relative to other systems, due to the annual solar cycle and the presence of sea-ice. High-latitude ecosystems are also subject to strong meteorological forcing (cold temperatures, strong winds) and concomitant vigorous vertical mixing of the upper water column which influences the phytoplankton light environment (Rey and Loeng, 1985).

At the same time that strong vertical mixing diminishes light for phytoplankton growth, it enhances the supply of essential macro-nutrients (nitrate, phosphate, silicate) to the surface ocean that support growth. High latitude ecosystems, in general, are characterized by moderate to high nutrient concentrations much of the year (Kamykowski and Zentara, 1985, 1986; Louanchi and Najjar, 2000) and the nature and extent of nutrient limitation of phytoplankton growth in these regions continues to be the subject of inquiry (Harrison and Cota, 1991).

The Labrador Sea and adjacent shelves comprise a biologically productive high-latitude ecosystem (Fig. 1) that is strongly influenced by all of the factors that modify phytoplankton growth. The Labrador Sea system forms part of the Northwest Atlantic sub-polar gyre and is delineated by strong boundary currents, associated with shallow continental shelves (the East and West Greenland coastal currents to the east and the Labrador Current to the west), and a deep central basin that undergoes strong vertical convective mixing in late winter (Lazier et al., 2002). Relatively warm, salty North Atlantic waters entering the central basin from the east and cold, fresh arctic waters enter over the continental shelves from the east and west, modifying water masses 


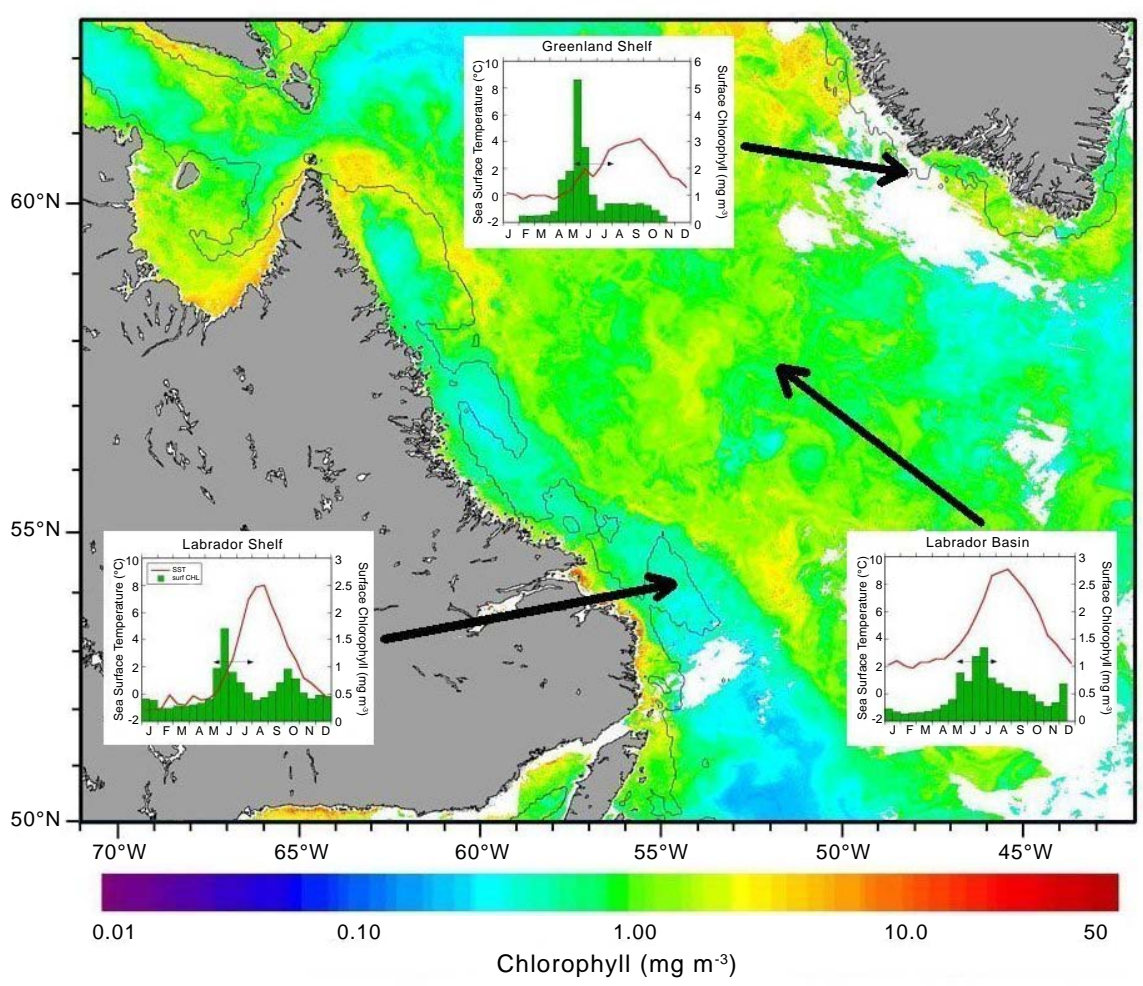

Fig. 1. Sea-viewing Wide Field-of-view Sensor (SeaWiFS) ocean colour composite image (July) of the Labrador Sea and surrounding waters. Inset graphs show average (1998-2004) twice-monthly satellite (AVHRR) sea surface temperature, SST, ${ }^{\circ} \mathrm{C}$ (red lines) and SeaWiFS surface chlorophyll concentration, $\mathrm{mg} \mathrm{m}^{-3}$ (green vertical bars) for: (lower left) the Labrador Shelf, (lower right) central Labrador basin and (top center) Greenland Shelf, see also Fig. 3. Horizontal lines in inset graphs indicate period of spring/summer LSMP observations.

and their physical, chemical and biological properties. From the standpoint of phytoplankton, light conditions and nutrient availability that determine seasonal growth cycles and community structure will be strongly influenced by the regional characteristics of circulation (mixing and transport) imposed by the complex of water masses making up the Labrador Sea system. As well, seasonal sea-ice dynamics of the Labrador and Greenland continental shelves will have a major effect on light conditions and water column stability, the latter affecting nutrient supply to the upper mixed-layer, that will influence phytoplankton growth.

Systematic observations of physical (temperature, salinity), chemical (nutrient concentrations) and biological (phytoplankton biomass and productivity) properties in the Labrador Sea have been made over the past 12 years (1994-2005) as part of the Labrador Sea Monitoring Program (LSMP). An analysis of these data, along with some historical data, provide most of the basic information required to evaluate the importance of light and nutrients in limiting the growth of phytoplankton in the region - the focus of this report.

\section{Methods}

Light and nutrient limitation, for the purposes of this analysis, are defined as the resource (light level or nutrient concentration) scaled by the physiological "rate constant" that determines the threshold value (level of light or concentration of nutrient) below which the rate process (photosynthesis in the case of light and nutrient uptake rate in the case of nutrients) is resource-limited.

For light, the resource is defined as the light level in the upper mixed-layer, given by the equation:

$$
I_{M L D}=I_{0}\left(1-e^{-K z \times M L D}\right) /(K z \times M L D)
$$

where $I_{M L D}=$ average irradiance in the mixed-layer $\left(\mathrm{Wm}^{-2}\right)$, $I_{0}=$ surface irradiance $\left(\mathrm{W} \mathrm{m}^{-2}\right), K z=$ vertical attenuation coefficient $\left(\mathrm{m}^{-1}\right)$ and $M L D=$ mixed-layer depth (m). The 
threshold parameter $\left(I_{t}, \mathrm{~W} \mathrm{~m} \mathrm{~m}^{-2}\right)$, often referred to as $I_{k}$ in the literature, is derived from the photosythesis-irradiance (P-I) curve (Fig. 2a). For nutrients, the resource is defined by the concentration of nutrient in the upper mixedlayer and the threshold parameter $\left(N_{t}, \mathrm{mmol} \mathrm{m}^{-3}\right)$, often referred to as $K_{s}$ in the literature, is derived from the Michalis-Menten concentration-dependent uptake curve (Fig. 2b). Resource-limitation (light or nutrients), or the potential for resource-limitation, was evaluated using a number of lines of evidence, including a comparison of climatological and observed light and nutrient levels in the Labrador Sea with limitation-threshold levels and modeled phytoplankton growth where light and nutrients limitation are interactive.

Observations from the Labrador Sea Monitoring Program (LSMP) used in this analysis came from annual spring-summer expeditions from 1994-2005 (Table 1). Twenty-eight nominal stations were occupied along a transect from the southern coast of Labrador to the southern coast of West Greenland (Fig. 3). For this analysis, data were averaged over all years and aggregated by month (May, June, July) within three defined regions: the Labrador Shelf/Slope (LS), The Labrador Basin (LB) and the Greenland Shelf/Slope (GS).

Surface irradiance and in-water light attenuation were measured on selected expeditions (1996-1999, 2001-2002, 2004; see Table 1) using $4 \pi$ photosynthetically active radiation (PAR, 400-700 nm) sensors (LICOR). Vertical attenuation coefficients $(\mathrm{Kz})$ were determined from the extinction of light from profiles of the upper $50 \mathrm{~m}$. Light was expressed in energy units based on the conversion factor: $1 \mathrm{~W} \mathrm{~m}^{-2}=4.6 \mu \mathrm{mol}$ quanta $\mathrm{m}^{-2} \mathrm{~s}^{-1}$. On expeditions where light was not measured, clear-sky irradiance was calculated using the formulations of Bird (1984) and corrected for cloud-fog attenuation at the surface based on mean light conditions during the missions where direct measurements were made. Consistently, measured surface irradiance was 52\% ( $\pm 2 \%$ ) of clear sky irradiance across all cruises/years, largely

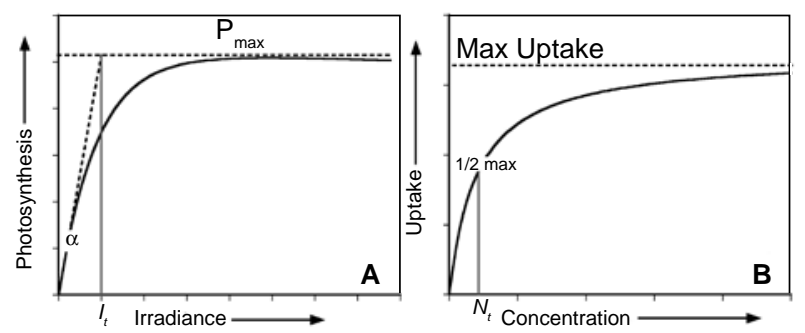

Fig. 2. Resource-dependent rate processes and threshold levels $\left(I_{t}\right.$ and $\left.N_{t}\right)$ used in the analysis of: (A) light and (B) nutrient-limitation, respectively. due to the prevailing meteorological conditions that characterize the spring/summer period in the Labrador Sea (Fig. 4). Mixed-layer depths (MLDs) were calculated from vertical density profiles of CTD (Seabird) casts and defined as the depth $(z)$ of maximum density gradient in the upper water column $(z \leq 100 \mathrm{~m})$. Nutrient concentrations for nitrate $\left(\mathrm{NO}_{3}\right)$, phosphate $\left(\mathrm{PO}_{4}\right)$, and silicate $\left(\mathrm{SiO}_{3}\right)$, were determined by autoanalyzer using standard colorimetric methods (Hansen and Grasshoff, 1983). Ammonium $\left(\mathrm{NH}_{4}\right)$ was also measured during the latter part of the study period (1999-2005) using the manual method of Solórzano (1969).

Photosynthesis-irradiance (P-I) experiments in nearsurface waters $(z \leq 25 \mathrm{~m})$ were conducted at a subset of stations (generally 5-8 of the 28 nominal stations) during each of the LSMP spring-summer missions (as well as during one mission in autumn and one in winter) using the method described by Platt et al., (1980). The light limitation threshold parameter, $I$, varied by season $(\sim 30$ $\mathrm{W} \mathrm{m}^{-2}$ in winter to $\sim 50 \mathrm{~W} \mathrm{~m}^{-2}$ in summer) but did not vary significantly by region. Nutrient uptake kinetics were not measured as part of the LSMP and, therefore, the nutrient limitation threshold parameter, $N_{t}$, for this analysis was taken from the literature. A number of recent studies in sub-polar seas suggest that the $N_{t}$ for $\mathrm{NO}_{3}$ and $\mathrm{SiO}_{3}$ would be in the range of $2-6 \mathrm{mmol} \mathrm{m}^{-3}$ (Kristiansen et al., 1994, 2000): a median value of $2 \mathrm{mmol} \mathrm{m}^{-3}$ was used for the present study (see also Hensen et al., 2006).

TABLE 1. Labrador Sea Monitoring Program (LSMP) missions and sampling dates, 1994-2005. NOTE: autumn/winter missions (96-026 and 02-075) were not included in this study.

\begin{tabular}{lcc}
\hline Mission & Year & L3 Line \\
\hline $94-008$ & 1994 & 26 May - 08 June \\
$95-016$ & 1995 & 10 July - 13 July \\
$96-006$ & 1996 & 18 May - 27 May \\
$96-026$ & 1996 & 20 October - 28 October \\
$97-009$ & 1997 & 21 May - 28 May \\
$98-023$ & 1998 & 26 June - 02 July \\
$99-022$ & 1999 & 01 July - 10 July \\
$00-009$ & 2000 & 24 May - 05 June \\
$01-022$ & 2001 & 04 June - 11 June \\
$02-032$ & 2002 & 02 July - 08 July \\
$02-075$ & 2002 & 01 December - 09 December \\
$03-038$ & 2003 & 23 July - 29 July \\
$04-016$ & 2004 & 20 May - 27 May \\
$05-016$ & 2005 & 29 May - 03 June \\
\hline
\end{tabular}




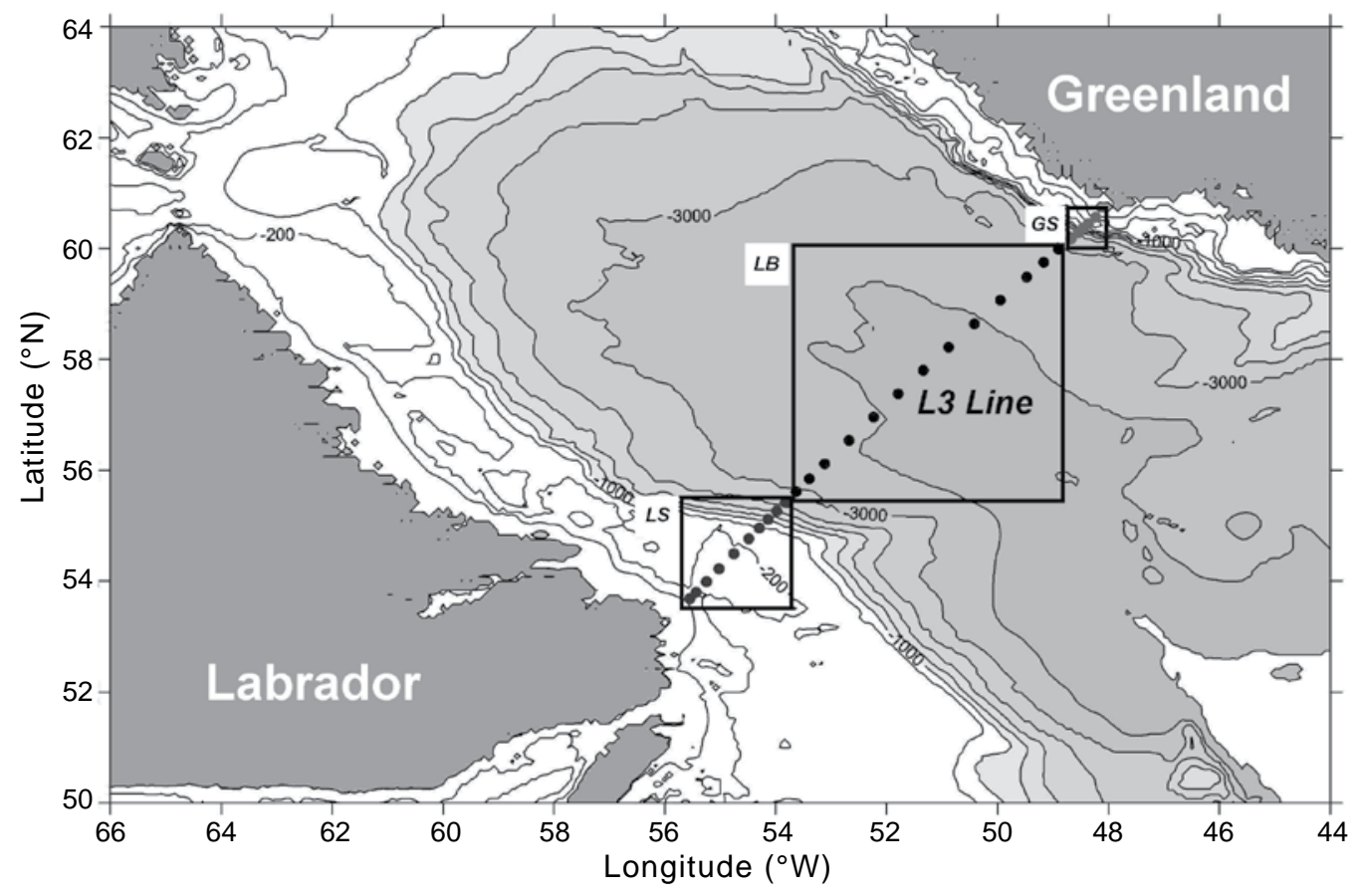

Fig. 3. Labrador Sea Monitoring Program (LSMP) station locations, L3-01 (Labrador) to L3-28 (Greenland) and sub-regions: Labrador Shelf/Slope, LS (L3-01 to L3-10); Labrador Basin, LB (L3-11 to L3-23); Greenland Shelf/Slope, GS (L3-24 to L3-28). Contours = bathymetry.
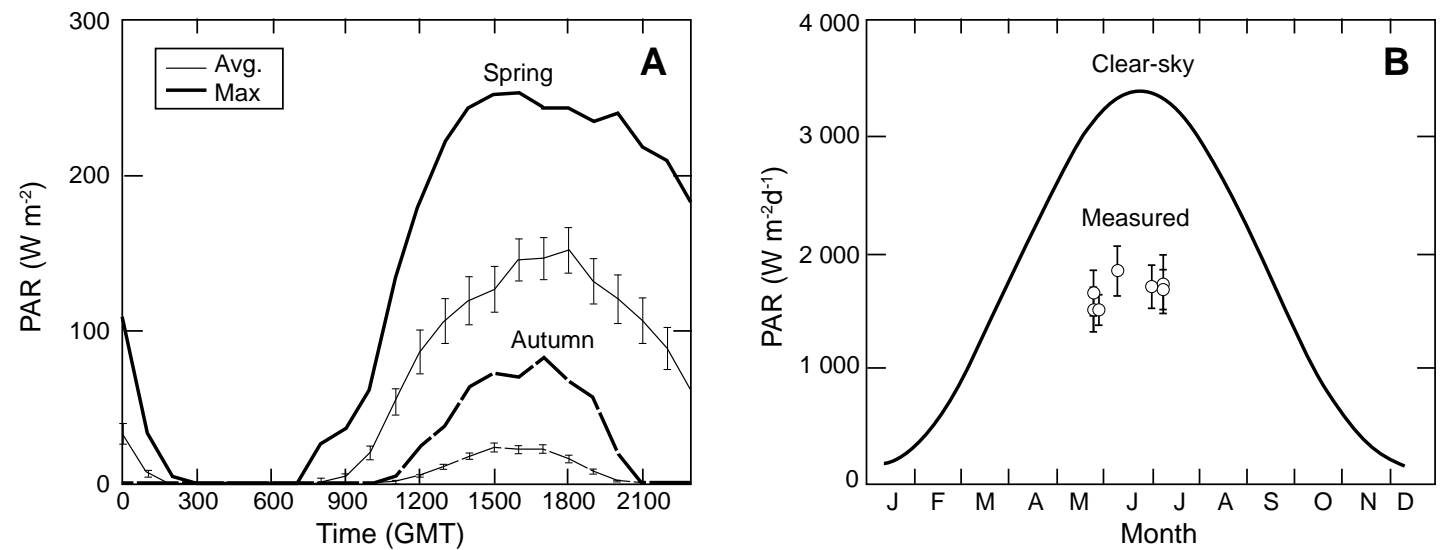

Fig. 4. Surface incident solar irradiance (PAR) cycles in the Labrador Sea: (A) daily cycle (maximum and average) of hourly energy fluxes from selected spring and autumn LSMP missions, (B) annual cycle of clear sky energy flux, (Bird, 1984) compared with average daily energy flux measured during spring and summer LSMP missions. Vertical bars $=$ standard errors (SE).

$\mathrm{PO}_{4}$ was not considered in this analysis since there is little evidence that concentrations are reduced to levels that would limit phytoplankton growth in sub-polar ecosystems (Harrison and Cota, 1991).

Climatological data (1962-2002, objectively analyzed mean fields, one degree spatial resolution) of mixed-layer depths and near-surface nutrient concentrations for the Labrador Shelf/Slope, Labrador Basin and the Greenland Shelf/Slope were extracted from the Na- tional Oceanographic Data Center (NODC) databases (http://www.nodc.noaa.gov/) (see also Monterey and Levitus, 1997; Garcia et al., 2006). Monthly mixed-layer depth irradiances $\left(I_{M L D}\right)$ were calculated (Eq. 1) using the climatological $M L D$ s and region/season averaged $\mathrm{Kz}$ values from LSMP observations.

The evaluation of light and nutrient-limitation often considers factors (thresholds of physiological processes) operating independently when it is known that light and 
nutrients act on phytoplankton growth and productivity in a synergistic way. To investigate the interplay of light and nutrient-limitation on phytoplankton growth per se, a simple phytoplankton growth model was employed which has been successfully used in coastal waters to quantify the sensitivity of phytoplankton growth to light and nutrients acting together (Cloern, 1999). This model, with some parameter adjustments, can be easily adapted for other marine environments such as the Labrador Sea. More complex mechanistic (cell-quota based) models may be considered a better choice for investigating the dynamics of multi-nutrient-light interactions (Flynn, 2001), however, parameter estimates required for these models from field observations is a real challenge and there are some circumstances where less complicated models are more appropriate (Flynn, 2003). The Cloern model, indeed, has the advantage of simplicity and parameterization that can be relatively easily derived from field observations, i.e. $N, I, N_{t}$, $I_{t}$. Moreover, it should adequately address questions of light and nutrient limitation under climatological mean conditions for large geographic areas which is the focus of our study. This growth model is based on the well-known saturation response of phytoplankton growth to light and nutrients (Fig. 2) and includes an interactive function such that, for example, phytoplankton growth at low light is enhanced by nutrient addition. This interactive term is not generally found in models that describe growth as the product or minimum of separate light and nutrientlimitation functions. More specifically, the model assesses the incremental change in phytoplankton growth with small, discrete changes in light or nutrient levels and expresses the relative effects of these changes on growth as a ratio $(R)$. The resultant $R$ ratios are indices that tell whether phytoplankton growth is more sensitive to light changes $(R>1)$ or to nutrient changes $(R<1)$. These ratios, in turn, can be plotted in a 2-D space where the major axes are another set of ratios, i.e. nutrient or light levels scaled to their corresponding threshold parameters, called the nutrient resource $\left(N / N_{t}\right)$ and light resource (I/I $)$ axes (Fig. 5). In this representation, although somewhat arbitrary (Cloern, 1999), $R$ values $>10$ represent the growth domain where light sensitivity dominates and is thus considered to be indicative of light-limited conditions, $R$ values $<0.1$, correspondingly, are considered indicative of nutrient-limited conditions and an $R$ of $0.1-10$ is indicative of conditions where co-limitation may occur.

\section{Results}

Mixed-layer depths (MLDs) varied by season and location (Fig. 6). Deepest MLDs occurred in March-April and were most pronounced in the central

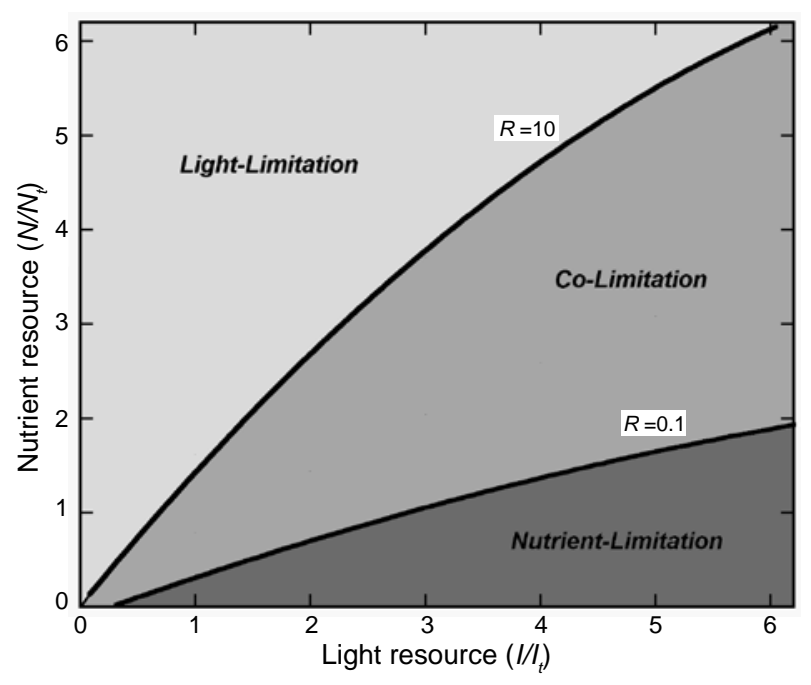

Fig. 5. Index $(R)$ of resource-limitation based on the sensitivity of phytoplankton growth rate to light and nutrient changes. $R$ = ratio of the incremental change in growth rate with change in light level or nutrient concentration; $R$ values greater $>10$ indicate light-limitation, values $<0.1$ indicate nutrient limitation and values 0.1-10 indicate co-limitation. $N=$ nutrient concentration, $N_{t}=$ nutrient-limitation threshold concentration, $I$ = light level, $I_{t}=$ light-limitation threshold level. Modified from Cloern (1999).

basin $(>300 \mathrm{~m})$; shallowest MLDs $(<10 \mathrm{~m})$ occurred May-Aug in all sub-regions. MLDs observed during the LSMP spring-summer missions were notably deeper (statistically significant; $p<0.01$ ) than climatological MLDs; deepest spring-summer MLDs were observed in the Labrador Basin. In all sub-regions, spring-summer MLDs were shallower (statistically significant, $p<0.01$ ) than euphotic depths.

MLD light levels $\left(I_{M L D}\right)$ also varied seasonally but were similar by location (Fig. 7). Maximum light levels $\left(70-80 \mathrm{~W} \mathrm{~m}^{-2}\right)$ were observed in summer when solar light is at its peak and MLDs shallowest (June-August): $I_{M L D}$ minimums $\left(<10 \mathrm{~W} \mathrm{~m}^{-2}\right)$ occurred in winter-spring (November-March) when solar light is lowest and MLDs deepest. Mixed-layer light levels observed during the LSMP spring-summer missions were notably lower (20-50 $\left.\mathrm{W} \mathrm{m}^{-2}\right)$ and statistically different $(p<0.01)$ from climatological levels $\left(40-80 \mathrm{~W} \mathrm{~m}^{-2}\right)$ due principally to the considerably deeper LSMP MLDs compared to the climatologies (Fig. 5). Climatological $I_{M L D}$ levels were higher than the light-limitation threshold $\left(I_{t}\right)$ from May-September and lower the remainder of the year. $I_{M L D}$ levels observed during the spring-summer LSMP missions, however, were similar to (Labrador Shelf) or somewhat lower than (Labrador Basin and Greenland 
Shelf) but not statistically different from the $I_{t}$ levels, even during summer peak light conditions.

Concentrations of nitrate $\left(\mathrm{NO}_{3}\right)$ in near-surface waters $(\mathrm{z} \leq 25 \mathrm{~m})$ varied by season in all regions (Fig. 8). Maximum climatological values $\left(9-10 \mathrm{mmol} \mathrm{m}^{-3}\right)$ were observed in spring (March-April), followed by a rapid decline due to biological consumption (Fig. 1, insets) with lowest concentrations throughout the summer and early autumn (July-September) after which concentra- tions began increasing again. Concentrations observed during the spring-summer LSMP missions were higher than climatological means on the Labrador Shelf (statistically significant, $p<0.05$ ) but similar to the climatologies in the Labrador Basin and on the Greenland Shelf. Similarly, minimum late summer (July) concentrations were lowest on the Labrador Shelf and below the $2 \mathrm{mmol}$ $\mathrm{m}^{-3}$ limitation threshold, $N_{t}$; late summer levels were higher than $N_{t}$ in the central basin and on the Greenland Shelf. Taking into consideration the climatological data

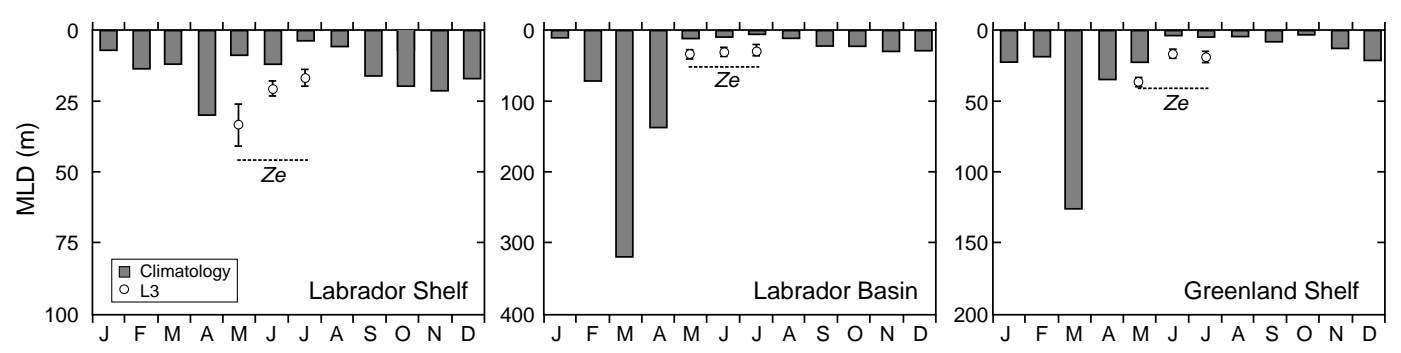

Fig. 6. Annual cycle of mixed-layer depths (MLD) in the Labrador Sea (partitioned into shelves and central basin): vertical bars = climatology (Monterey and Levitus, 1997), points = average values derived from LSMP spring and summer missions (vertical lines = standard errors, SE). Horizontal dashed line $=$ average observed spring-summer euphotic zone depth $(\mathrm{Ze}=4.6 / \mathrm{Kz})$. Note difference in vertical (depth) scales.
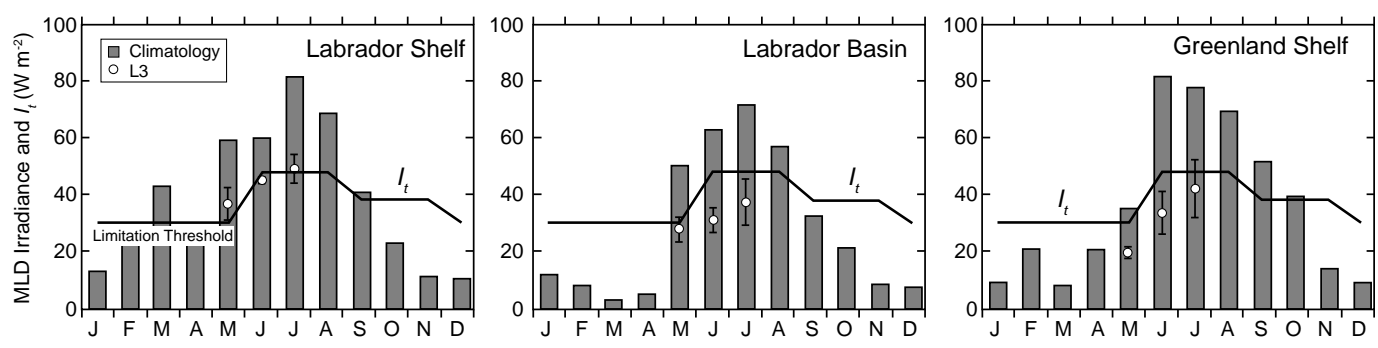

Fig. 7. Annual cycle of mixed-later depth irradiance levels $\left(I_{M L D}\right)$ in the Labrador Sea (partitioned into shelves and central basin): vertical bars = climatology, points = average values from LSMP spring and summer missions (vertical lines = standard errors, SE). Solid line = light-limitation threshold parameter $\left(I_{t}\right) . I_{t}$ levels in winter and spring were statistically indistinguishable but statistically different from summer $(p<0.01)$ and autumn $(p<0.10)$ levels.
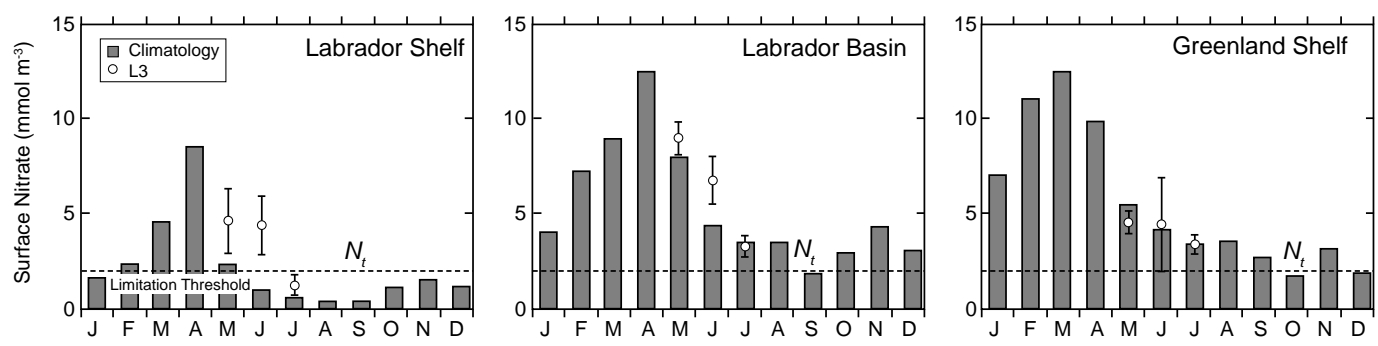

Fig. 8. Annual cycle of surface nitrate $\left(\mathrm{NO}_{3}\right)$ concentrations $\left(\mathrm{mmol} \mathrm{m}^{-3}\right)$ in the Labrador Sea (partitioned into shelves and central basin): vertical bars = climatology (Garcia et al., 2006), points = average values from LSMP spring and summer missions (vertical lines = standard errors, SE). Dashed line = $\mathrm{NO}_{3}$-limitation threshold parameter $\left(N_{t}\right)$. 
and LSMP observations overall, $\mathrm{NO}_{3}$ concentrations are higher in the central basin and on the Greenland Shelf than on the Labrador Shelf (statistically significant, $p<0.05$ ). Another consideration in evaluating nitrogen limitation in these waters is the fact that reduced forms of inorganic nitrogen (e.g. ammonium, $\mathrm{NH}_{4}$ ) are also important for phytoplankton nitrogen nutrition. However, in the Labrador Sea, $\mathrm{NH}_{4}$ concentrations are consistently low $\left(<0.5 \mathrm{mmol} \mathrm{m}^{-3}\right)$ in near surface waters in all regions and show no discernible pattern by geographic location or by season. It was determined that the inclusion of $\mathrm{NH}_{4}$ (to get a more complete assessment of the nitrogen available for phytoplankton growth) would not have significantly changed the results or conclusions of this study and since only a subset of stations were sampled for $\mathrm{NH}_{4}$, it was considered best to confine our analysis to $\mathrm{NO}_{3}$ only.

Near-surface $(z \leq 25 \mathrm{~m})$ silicate $\left(\mathrm{SiO}_{3}\right)$ concentrations followed a similar seasonal cycle except that extremes (spring maxima-summer minima) were not as large and, overall, concentrations were similar among the three sub-regions, i.e. not statistically different (Fig. 9). Surface $\mathrm{SiO}_{3}$ concentrations differed from $\mathrm{NO}_{3}$, however, in that late summer (July) levels were at or be- low the $2 \mathrm{mmol} \mathrm{m}^{-3}$ threshold concentration $\left(N_{t}\right)$ in all sub-regions. Overall, regional differences in $\mathrm{SiO}_{3}$ concentrations are less evident than differences in $\mathrm{NO}_{3}$ concentrations.

$\mathrm{NO}_{3}$ versus $\mathrm{SiO}_{3}$ scatter plots for the LSMP data revealed some general patterns (Fig. 10, Table 2): (i) evidence of $\mathrm{NO}_{3}$ depletion in the presence of measurable $\mathrm{SiO}_{3}$ concentrations, seen predominantly on the Labrador Shelf in spring (Fig. 10, left panel); (ii) evidence of $\mathrm{SiO}_{3}$ depletion in the presence of measurable $\mathrm{NO}_{3}$, seen predominantly in the central Labrador Basin in summer (Fig. 10, center panel); and (iii) evidence of simultaneous $\mathrm{NO}_{3}$ and $\mathrm{SiO}_{3}$ depletion, a feature observed often on the Greenland Shelf in spring and summer (Fig. 10, right panel). These results provide strong site-specific evidence of both $\mathrm{NO}_{3}$ and $\mathrm{SiO}_{3}$ limitation that were less evident in analysis of climatolgical mean conditions where some degree of spatial and temporal averaging is used, i.e. Figs. 8 and 9.

Climatological and LSMP spring-summer light and nutrient data and their corresponding threshold values were used with Cloern's model (Fig. 5) to evaluate light and nutrient limitation in the Labrador Sea and results are
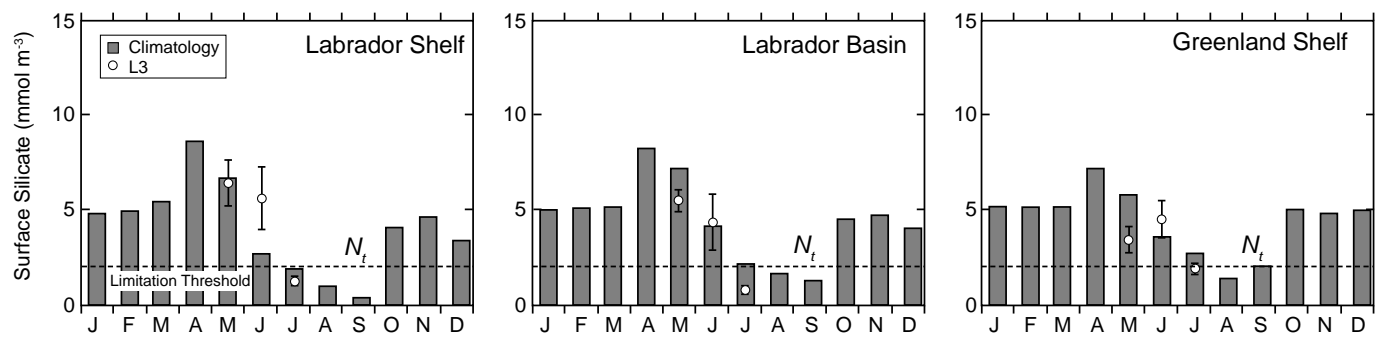

Fig. 9. Annual cycle of surface silicate $\left(\mathrm{SiO}_{3}\right)$ concentrations $\left(\mathrm{mmol} \mathrm{m}^{-3}\right)$ in the Labrador Sea (partitioned into shelves and central basin): vertical bars = climatology (Garcia et al., 2006), points = average values from LSMP spring and summer missions (vertical lines = standard errors, SE). Dashed line = $\mathrm{SiO}_{3}$-limitation threshold parameter $\left(N_{t}\right)$.
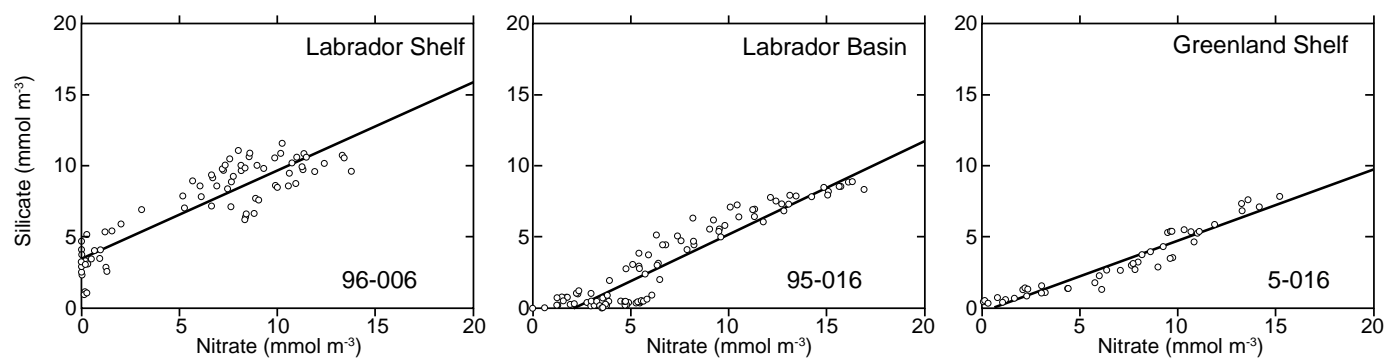

Fig. 10. Examples of nitrate $\left(\mathrm{NO}_{3}\right)$ versus silicate $\left(\mathrm{SiO}_{3}\right)$ concentration scatter plots of data from the upper $100 \mathrm{~m}$ for LSMP spring and summer missions showing: (left panel) $\mathrm{NO}_{3}$-depleted conditions on the Labrador Shelf, (center panel) $\mathrm{SiO}_{3}$-depleted condition in the central Labrador Basin, and (right panel) co-depleted conditions on the Greenland Shelf. Solid lines = least squares linear regression fits. 
TABLE 2. Least squares linear regression coefficients (slope, $\mathrm{SiO}_{3}: \mathrm{NO}_{3}$ and intercept, $\mathrm{mmol} \mathrm{m} \mathrm{m}^{-3}$ ) from nitrate versus silicate plots (data from $<100 \mathrm{~m}$ ): Labrador Sea (L3 Line) spring and summer missions. $\mathrm{YD}=$ year-day, $\mathrm{Int}-\mathrm{Si}=$ intercept on $\mathrm{SiO}_{3}$-axis, and $\mathrm{Int}-\mathrm{N}=$ intercept on $\mathrm{NO}_{3}$-axis.

\begin{tabular}{|c|c|c|c|c|c|c|c|c|c|c|}
\hline \multirow[b]{2}{*}{ Mission } & \multirow[b]{2}{*}{ Mean YD } & \multicolumn{3}{|c|}{ Labrador Shelf/Slope } & \multicolumn{3}{|c|}{ Labrador Basin } & \multicolumn{3}{|c|}{ GreenlandShelf/Slope } \\
\hline & & Slope & Int-Si & Int-N & Slope & Int-Si & Int-N & Slope & Int-Si & Int-N \\
\hline $96-006$ & 143 & 0.62 & 3.52 & - & 0.44 & 1.52 & - & 0.12 & 4.60 & - \\
\hline 04-016 & 145 & -0.07 & 9.86 & - & 0.38 & 2.55 & - & 0.51 & 0.83 & - \\
\hline $97-009$ & 146 & 0.74 & 4.82 & - & 0.56 & 0.35 & - & 0.43 & 1.62 & - \\
\hline 00-009 & 151 & -0.13 & 9.96 & - & 0.28 & 4.14 & - & 0.33 & 4.26 & - \\
\hline 05-016 & 152 & 0.49 & 3.98 & - & 0.45 & 0.56 & - & 0.50 & - & 0.52 \\
\hline 01-022 & 159 & 0.24 & 6.19 & - & 0.51 & 0.27 & - & 0.56 & 0.30 & - \\
\hline $98-023$ & 181 & 0.75 & 1.14 & - & 0.58 & - & 2.90 & 0.75 & 1.14 & - \\
\hline 02-032 & 186 & 0.55 & 0.39 & - & 0.64 & - & 2.42 & 0.49 & 0.76 & - \\
\hline $99-022$ & 187 & 0.61 & 0.90 & - & 0.65 & - & 2.68 & 0.54 & - & 0.44 \\
\hline $95-016$ & 193 & 1.07 & 0.54 & - & 0.66 & - & 1.97 & 0.45 & 0.85 & - \\
\hline 03-038 & 208 & 0.68 & 1.13 & - & 0.51 & - & 0.25 & 0.33 & 1.04 & - \\
\hline
\end{tabular}
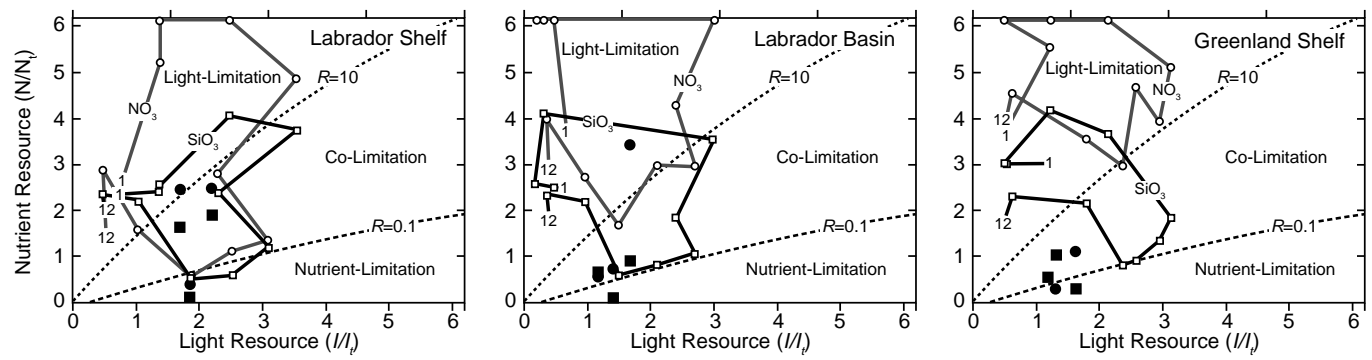

Fig. 11. Light and/or nutrient-limitation of phytoplankton growth (see Fig. 5) under conditions observed in the Labrador Sea (partitioned into shelves and central basin): Solid grey $\left(\mathrm{NO}_{3}\right)$ and black $\left(\mathrm{SiO}_{3}\right)$ lines are based on monthly ( 1 = January, 12 = December) climatological conditions of light and nutrients and red and blue points are based on average spring and summer conditions observed during LSMP missions (1994-2005). For these plots, the Nutrient Resource axis $=\mathrm{NO}_{3}$ conc. or $\mathrm{SiO}_{3}$ conc. $/ N_{t}$ and the Light Resource axis $=I_{M L D} / I_{t}$.

summarized in Fig. 11. Note that environmental growth conditions and physiological rate parmeters in the Labrador Sea were in some cases different from the input variables used in Cloern's coastal-temperate phytoplankton growth model (e.g. lower temperatures, deeper mixedlayers, less light attenuation, lower P-I parameters in the Labrador Sea). The $R$ curves in Fig. 11 were adjusted accordingly. The solid lines in the figure trace the seasonal progression of the climatological data, indicating light-limited growth in late winter to early spring, colimitation or nutrient-limited growth in summer/autumn back to light limitation in late autumn to end of the year. Noteworthy in these plots is the progressive separation of the $\mathrm{NO}_{3}$ and $\mathrm{SiO}_{3}$ traces, i.e. N-limited growth in summer is evident only on the Labrador Shelf whereas Si- limited growth is evident in all sub-regions. On the other hand, LSMP data suggest some $\mathrm{N}$ - and Si-limited growth in all regions in summer.

\section{Discussion}

The importance of light in limiting the production and growth of high-latitude phytoplankton is well established and has been the subject of numerous studies and publications over the past several decades. Much of this work, however, due to limitations in accessibility to field study sites, has been restricted to peak phytoplankton growth season (summer) when light conditions are most favorable. In most studies, the physiological characteristics of the populations have been the focus (Har- 
rison and Platt, 1986; Rey, 1991; Sakshaug and Slagstad, 1991). Only from established time-series stations has a more complete picture (annual time scale) of light influence on phytoplankton growth been possible, e.g. Ocean Weather Station M $\left(66^{\circ} \mathrm{N}, 2^{\circ} \mathrm{E}\right)$ in the Norwegian Sea (Rey, 2004). Our study has consolidated information on seasonal mixed-layer dynamics, incident solar irradiance and in-water light attenuation in the Labrador Sea from the past 12 years to suggest that light is the principal limiting factor of phytoplankton production and growth for most of the year. Indeed, there is evidence from this analysis that light may limit growth even during summer when incident radiation is at its maximum. Sea-ice dynamics will also have an additional strong influence on light conditions for phytoplankton growth in this region, particularly on the Labrador Shelf. This will be the subject of future analysis.

The influence of nutrients on phytoplankton production and growth, as the case with light, has been the subject of numerous studies in high-latitude ecosystems and again, most of this work has been confined to process studies during peak summer growth. In this case, however, it is only during peak summer growth that surface nutrients are reduced to levels limiting to phytoplankton. Therefore, information on annual nutrient
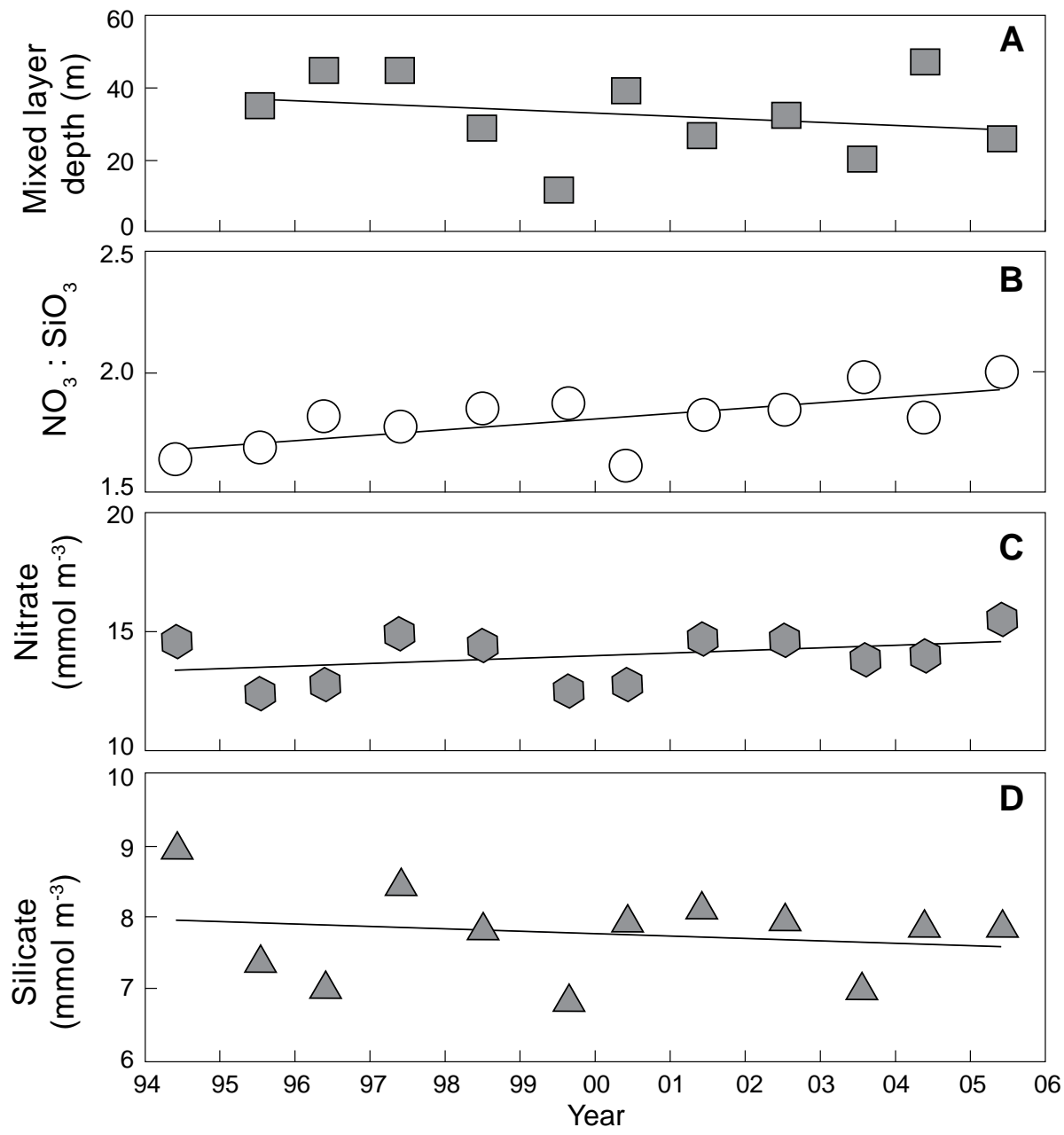

Fig. 12. Multiyear record of oceanographic conditions during spring/summer in the central Labrador Sea basin. (A) mixed layer depth: slope $(b)=-0.852 \mathrm{~m} \mathrm{y}^{-1}$, correlation coef. $(r)=0.26$, significance $(p)=0.44,(\mathbf{B})$ ratio of $\mathrm{NO}_{3}: \mathrm{SiO}_{3}$ at $100 \pm 20 \mathrm{~m}: b=0.0156 \mathrm{y}^{-1}$, $r=0.53, p=0.06,(\mathbf{C}) \mathrm{NO}_{3}$ concentration at $100 \pm 20 \mathrm{~m}: b=0.0897 \mathrm{mmol} \mathrm{m}^{-3} \mathrm{y}^{-1}$, $r=0.34$, significance $(p)=0.25$, (D) $\mathrm{SiO}_{3}$ concentration at $100 \pm 20 \mathrm{~m}: b=-0.0157$ $\mathrm{mmol} \mathrm{m} \mathrm{y}^{-1}, r=0.10, p=0.74$. 
dynamics may not add much more to the understanding of phytoplankton nutrient-limitation per se, beyond what seasonally restricted studies reveal. However, knowledge of the extent of winter mixing (and recharge of surface waters with nutrients) can contribute to a better understanding of the amplitude and duration of the phytoplankton growth cycle and the relative proportions of macronutrients (e.g. $\mathrm{NO}_{3}$ and $\mathrm{SiO}_{3}$ ) in source waters may help explain regional and/or temporal variability in phytoplankton community structure (see below). In the Labrador Sea where strong winter convective mixing and summer density re-stratification are characteristic features (Lazier et al., 2002), where phytoplankton production is significant (Fig. 1) and where surface nutrient concentrations are reduced, the potential for some degree of nutrient-limitation is certain. Several lines of evidence presented here suggest that there is potential for both nitrogen and silicon limitation in the Labrador Sea in summer and that nitrate-limitation is more likely on the Labrador Shelf while silicate-limitation is more likely in the central basin. Furthermore, an evaluation of the relative roles of light and nutrients on phytoplankton growth based on a simple phytoplankton growth model, suggests that co-limitation is likely in all regions during the peak summer growth season.

The assumptions made in this study were based on experimentally derived threshold values for light $\left(I_{t}\right.$ or $\left.I_{k}\right)$ and literature-derived values for nutrients $\left(N_{t}\right.$ or $K_{s}$ ). We are reasonably confident that our seasonally varying $I_{t}$ values are representative of phytoplankton for sub-polar regions; we have made extensive measurements during the LSMP and our values are consistent with values reported in other regional studies, (Harrison and Platt, 1986; Rey, 1991). The $N_{t}$ values we used are relatively conservative (i.e. median value of the reported range) and assumed to be seasonally invariant. There are a number of studies, however, that suggest that the threshold parameter is not constant but is adaptive and adjusts to the prevailing nutrient conditions (Harrison et al., 1996; Kristiansen et al., 1994, 2000), i.e. as nutrient concentrations decrease the threshold parameter decreases and thus the "affinity" for the diminishing nutrient resource increases. If the limitation threshold values we used are too high for summer conditions, for example, then the extent of nutrient-limitation would be reduced relative to our assessment (i.e., the lines and data points in Fig. 11 would be shifted up more into the light-limited domain). Cloern (1999) conducted a detailed sensitivity analysis to explore the effects of parameter estimates on his model results. His analysis showed that resource limitation boundaries (i.e. the $R$ curves in Fig. 5) changed little with a change in growth temperature of $20^{\circ} \mathrm{C}$, however, boundaries shifted as much as $\pm 30 \%$, at high light resource $\left(I / I_{t}\right)$ levels, when $N_{t}$ values were doubled/halved. This is on the order of uncertainty we expect in applying this model to the Labrador Sea, especially considering the relatively large observed range in $N_{t}$ levels in sub-polar waters.

There are additional considerations for silicate that could influence the outcome of our analyses. For example, $N_{t}$ values have been seen to vary considerably during the phytoplankton growth cycle in the Southern Ocean for reasons unclear to the investigators (Nelson et al., 2001). In other studies, concentration-dependent silicate uptake does not saturate and continues to increase over the full range of ambient silicate concentrations (Brown et al., 2003). If the latter situation is relevant to the Labrador Sea, then another approach altogether would be required to assess silicate-limitation in these waters.

The analyses of LSMP data described thus far deal with average conditions (1994-2005); inter-annual variability in mixing, nutrients and plankton are being explored but are not reported here. However, a preliminary look at long-term trends in mixed-layer depths as well as source water (below MLD, $100 \pm 20 \mathrm{~m}$ ) $\mathrm{NO}_{3}$ and $\mathrm{SiO}_{3}$ concentrations suggests a shallowing $\left(\sim 0.9 \mathrm{~m} \mathrm{y}^{-1}\right)$ in MLDs, an increase $\left(\sim 0.09 \mathrm{mmol} \mathrm{m}^{-3} \mathrm{y}^{-1}\right)$ in $\mathrm{NO}_{3}$ and a decrease in $\mathrm{SiO}_{3}\left(\sim 0.02 \mathrm{mmol} \mathrm{m}^{-3} \mathrm{y}^{-1}\right)$, the latter resulting in a statistically significant $(p<0.06)$ increase in sourcewater $\mathrm{NO}_{3}: \mathrm{SiO}_{3}$ ratios over the past 12 years in the central Labrador Sea basin (Fig. 12). This has occurred at the same time that surface seawater temperatures have been increasing (Yashayaev et al., 2003; Hendry, 2006; Yashayaev and Clarke, 2006) and phytoplankton abundance and community structure has been changing ( $\mathrm{Li}$ et al., 2006). Observations indicate that bulk chlorophyll during spring has been decreasing in the Labrador Sea while small forms, $<10 \mu \mathrm{m}$ (picoplankton and nanoplankton), have been increasing over the past decade. By inference (and difference), large (>10 $\mu \mathrm{m})$ phytoplankton have decreased over time. If a major component of the large phytoplankton in these waters is comprised of diatoms (Hensen et al., 2006) then the question arises, is the observed decrease in source-water $\mathrm{SiO}_{3}$ linked to the apparent decrease in silicate-requiring diatoms? More generally, can the observed changes in $\mathrm{NO}_{3}$ and $\mathrm{SiO}_{3}$ be linked to changes in larger-scale circulation (altered advective transport and modification of major water-mass properties), i.e. are the increasing $\mathrm{NO}_{3}: \mathrm{SiO}_{3}$ ratios related to changes in the relative contributions of North Atlantic and arctic waters entering the Labrador Sea?

Recent analysis of decadal changes in satellite-based sea-surface temperature and ocean colour (Behrenfeld et al., 2006) suggest that global warming may enhance 
phytoplankton productivity in high-latitude regions due to decreased surface mixing, shallowing MLDs and improved light conditions for phytoplankton growth (Doney, 2006). Our LSMP data suggest that MLDs may be decreasing as water temperatures increase, however, overall phytoplankton biomass (bulk chlorophyll) appears to be decreasing, not increasing (Li et al., 2006). Changes we are seeing in source water nutrient ratios and in phytoplankton community structure suggest that Doney's conceptual model captures only part of the dynamics that will link climate change to response at the base of the marine food web. Understanding the primary environmental control factors (light, nutrients) on phytoplankton growth and community structure is a key element in establishing how "first-order" changes in environmental properties, such as temperature increase and ice melt through climate variability/change, will induce changes, "second-order effects", in mixing, light and nutrients conditions that more directly effect structure and function of biological communities.

\section{Acknowledgements}

The authors wish to acknowledge the research scientists and technical staff of the Ocean Sciences and Ecosystem Research Divisions and officers and crew of the CCGS Hudson who have supported the Labrador Sea Monitoring Program (LSMP) for the past 12 years. We wish to thank, in particular, M. Kennedy, C. Porter and J. Anning for assistance in data analysis. The Program of Energy Research and Development (PERD) was a major source of financial support for this study and for LSMP.

\section{References}

BEHRENFELD, M. J., R. T. O’MALLEY, D. A. SIEGEL, C. R. MCCLAIN, J. L. SARMIENTO, G. C. FELDMAN, A. J. MILLIGAN, P. G. FALKOWSKI, R. M. LETELIER, and E. S BOSS. 2006. Climate-driven trends in contemporary ocean productivity. Nature, 44: 752-755. doi:10.1038/nature05317

BIRD, R. E. 1984. A simple, solar spectral model for directnormal and diffuse horizontal irradiance. Solar Energy, 32: 461-471. doi:10.1016/0038-092X(84)90260-3

BROWN, L., R. SANDERS, G. SAVIDGE, and C. H. LUCAS. 2003. The uptake of silica during the spring bloom in the Northeast Atlantic Ocean. Limnol. Oceanogr., 48: 1831-1845.

CLOERN, J. E. 1999. The relative importance of light and nutrient limitation of phytoplankton growth: a simple index of coastal ecosystem sensitivity to nutrient enrichment. Aquat. Ecol., 33: 3-16. doi:10.1023/A:1009952125558

DONEY, S. C. 2006. Plankton in a warmer world. Nature, 44: 695-696. doi:10.1038/444695a
FLYNN, K. J. 2001. A mechanistic model for describing dynamic multi-nutrient, light, temperature, interactions in phytoplankton. J. Plankton Res., 23: 977-997.

2003. Do we need complex mechanistic photoacclimation models for phytoplankton? Limnol. Oceanogr., 48: 2243-2249. doi:10.1093/plankt/23.9.977

FRANCIS, R. C. (ed.). 1996. The Bering Sea ecosystem. National Academy Press, Washington, D.C., 308 p.

GARCIA, H. E., R. A. LOCARNINI, T. P. BOYER, and J. I. ANTONOV. 2006. World Ocean Atlas 2005, Volume 4: Nutrients (phosphate, nitrate, silicate). NOAA Atlas NEDIS 64, U.S. Gov. Printing Office, Washington, D.C., $396 \mathrm{p}$.

GRAY, J. S., and M. E. CHRISTIANSEN. 1985. Marine Biology of Polar Regions and Effects of Stress on Marine Organisms. John Wiley and Sons Ltd., Chichester, 639 p.

HANSEN, H. P., and K. GRASSHOFF. 1983. Procedures for the automated determination of seawater constituents. In: Methods of seawater analysis: 2nd Ed. K. Grasshoff, M. Ehrhardt and K. Kremling (eds.). Verlag Chemie, Weinheim, p. 362-379.

HARRISON, W. G., and G. F. COTA. 1991. Primary production in polar waters: relation to nutrient availability. Polar Res., 10: 87-104. doi:10.1111/j.1751-8369.1991. tb00637.x

HARRISON, W. G., and T. PLATT. 1986. Photosynthesisirradiance relationships in polar and temperate phytoplankton populations. Polar Biol., 5: 153-164. doi:10.1007/ BF00441695

HARRISON, W. G., L. R. HARRIS, and B. D. IRWIN. 1996. The kinetics of nitrogen utilization in the cceanic mixed layer: nitrate and ammonium interactions at nanomolar concentrations. Limnol. Oceanogr., 41: 16-32.

HENDRY, R. 2006. Upper-ocean variability in the Labrador Sea in recent years. AZMP/PMZA Bull., 5: 10-12.

HENSEN, S. A., R. SANDERS, C. HOLETON, and J. T. ALLEN. 2006. Timing of nutrient depletion, diatom dominance and a lower-boundary estimate of export production for Irminger Basin, North Atlantic. Mar. Ecol. Prog. Ser., 313: 73-84. doi:10.3354/meps313073

KAMYKOWSKI, D., and S.-J. ZENTARA. 1985. Nitrate and silicic acid in the world ocean: patterns and processes. Mar. Ecol. Prog. Ser., 26: 47-59. doi:10.3354/meps026047

1986. Predicting plant nutrient concentrations from temperature and sigma-t in the upper kilometer of the world ocean. Deep-Sea Res. A Oceanogr. Res. Pap., 33: 89-105. doi:10.1016/0198-0149(86)90109-3

KRISTIANSEN, S., T. FABROT, and L.-J. NAUSTVOLL. 2000. Production of biogenic silica by spring diatoms. Limnol. Oceanogr., 45: 472-478.

KRISTIANSEN, S., T. FABROT, and P. A. WHEELER. 1994. Nitrogen cycling in the Barents Sea - Seasonal dynamics of new and regenerated production in the marginal ice zone. Limnol. Oceanogr., 39: 1630-1642.

LAZIER, J., R. HENDRY, A. CLARKE, I. YASHAYAEV, and P. RHINES. 2002. Convection and restratification in the Labrador Sea, 1990-2000. Deep-Sea Res. I Oceanogr. Res. Pap., 49: 1819-1835. doi:10.1016/S09670637(02)00064-X 
LI, W. K. W., W. G. HARRISON, and E. J. H. HEAD. 2006. Coherent sign switching in multiyear trends of microbial plankton. Science, 311: 1157-1160. doi:10.1126/science. 1122748

LONGHURST, A. R. 1981. Analysis of marine ecosystems. Academic Press. London, 741 p.

2006. Ecological geography of the sea, $2^{\text {nd }}$ Edition. Academic Press. Amsterdam, 542 p.

LOUANCHI, F., and R. G. NAJJAR. 2000. A global monthly climatology of phosphate, nitrate, and silicate in the upper ocean: Spring-summer export production and shallow remineralization. Global Biogeochem. Cycles., 14: 957-977. doi:10.1029/1999GB001215

MONTEREY, G., and S. LEVITUS. 1997. Seasonal variability of mixed layer depth for the world ocean. NOAA Atlas NESDIS 14. U.S. Gov. Printing Office, Washington, D.C., $96 \mathrm{p}$.

NELSON, D. M., M. A. BRZEZINSKI, D. E. SIGMON, and V. M. FRANCK. 2001. A seasonal progression of Si limitation in the Pacific sector of the Southern Ocean. Deep-Sea Res. II Top. Stud. Oceanogr., 48: 3973-3995. doi:10.1016/S0967-0645(01)00076-5

PLATT, T., C. L. GALLEGOS, and W. G. HARRISON. 1980. Photoinhibition of photosynthesis in natural assemblages of marine phytoplankton. J. Mar. Res., 38: 687-701.

REY, F. 1991. Photosynthesis-irradiance relationships in natural phytoplankton populations of the Barents Sea. Po- lar Res., 10: 105-116. doi:10.1111/j.1751-8369.1991. tb00638.x

2004. Phytoplankton: the grass of the sea. In: The Norwegian sea ecosystem. H.R. Skjoldal, R. Sætre, A. Farnö, O.A. Misund and I. Røttingen (eds.). Tapir Academic Press, Trondheim, p. 97-136.

REY, F., and H. LOENG. 1985. The influence of ice and hydrographic conditions on the development of phytoplankton in the Barents Sea. In: Marine biology of polar regions and effects of stress on marine organisms. J. S. Gray and M. E. Christiansen (eds.). John Wiley and Sons, Ltd., Chichester, p. 49-63.

SAKSHAUG E., and D. SLAGSTAD. 1991. Light and productivity of phytoplankton in polar marine ecosystems: a physiological view. Polar Res., 10: 69-85. doi:10.1111/ j.1751-8369.1991.tb00636.x

SKJOLDAL, H. R. (ed.). 2004. The Norwegian sea ecosystem. Tapir Academic Press, Trondheim, Norway, 559 p.

SOLÓRZANO, L. 1969. Determination of ammonia in natural waters by the phenolhypochlorite method. Limnol. Oceanogr., 14: 799-801.

YASHAYAEV, I., and R. A. CLARKE. 2006. Recent warming of the Labrador Sea. Atlantic Zone Monitoring Program Bulletin, 5: 12-20.

YASHAYAEV, I., J. R. N. LAZIER, and R. A. CLARKE. 2003. Temperature and salinity in the central Labrador Sea during the 1990s and in the context of the longer-term change. ICES Mar. Sci. Symp., 219: 32-39. 